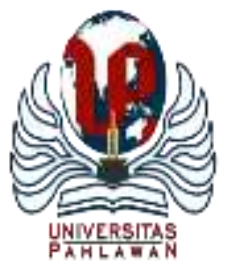

Edukatif : Jurnal Ilmu Pendidikan Volume 3 Nomor 6 Tahun 2021 Halm 3993 - 4006

EDUKATIF: JURNAL ILMU PENDIDIKAN

Research \& Learning in Education

https://edukatif.org/index.php/edukatif/index

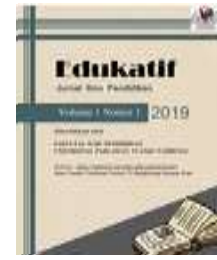

\title{
Peningkatan Kompetensi Pedagogik melalui Pelatihan Teknologi Informasi Komunikasi dan Pendampingan Kepala Sekolah pada Masa Pandemi Covid-19 di Sekolah Dasar
}

\author{
Yufita $^{1}$, Hotmaulina Sihotang ${ }^{\bowtie 2}$, Witarsa Tambunan ${ }^{3}$ \\ SDS Pelita Jakarta, Indonesia ${ }^{1}$ \\ Univeritas Kristen Indonesia, Indonesia ${ }^{2,3}$

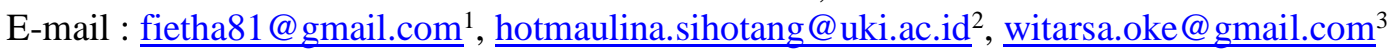

\begin{abstract}
Abstrak
Pandemi covid-19 telah membawa perubahan terhadap kegiatan pendidikan dan pembelajaran di sekolah. Guru dituntut untuk dapat menyampaikan pembelajaran dengan memanfaatkan perangkat Teknologi Informasi Komunikasi (TIK). Rendahnya kompetensi pedagogik guru dalam memanfaatkan perangkat TIK mendasari penelitian tindakan sekolah ini. Penelitian tindakan sekolah ini dilakukan dengan tujuan untuk mendapatkan gambaran terhadap peningkatan kompetensi pedagogik guru setelah mendapatkan pelatihan pemanfaatan Teknologi Informasi Komunikasi (TIK) khususnya pelatihan pembuatan media presentasi pembelajaran menggunakan microsoft power point dan pendampingan kepala sekolah. Penelitian tindakan sekolah ini dilakukan di SDS Pelita, Jakarta Barat, dengan jumlah responden 10 orang guru kelas. Analisis komparatif dilakukan terhadap hasil penelitian untuk membandingkan hasil penelitian di setiap siklus. Hasil dari penelitian tindakan sekolah ini didapatkan adanya peningkatan kompetensi pedagogik guru dalam pemanfaatan TIK dari siklus 1 sebesar 50\% menjadi 100\% pada siklus ke-2. Maka dapat disimpulkan bahwa pelatihan TIK dan pendampingan kepala sekolah dapat meningkatkan kompetensi pedagogik guru dalam mengajar dengan menggunakan perangkat TIK.
\end{abstract}

Kata Kunci: Kompentensi, Pedagogik, Pelatihan, Pendampingan, TIK.

\begin{abstract}
The COVID-19 pandemic has brought changes to education and learning activities in schools. Teachers are required to be able to deliver learning by utilizing Information and Communication Technology (ICT) devices. The low pedagogic competence of teachers in utilizing ICT tools underlies this school action research. This school action research was conducted with the aim of getting an overview of the improvement of teacher pedagogic competence after receiving training in the use of Information and Communication Technology (ICT), especially training in making learning presentation media using Microsoft Power Point, and mentoring school principals. This school action research was conducted at SDS Pelita, West Jakarta, with a total of 10 classroom teachers as respondents. Comparative analysis was carried out on the research results to compare the results of the research in each cycle. The results of this school action research showed an increase in teacher pedagogic competence in the use of ICT from cycle 1 by 50\% to $100 \%$ in cycle 2. So it can be concluded that ICT training and mentoring of school principals can improve the pedagogic competence of teachers in teaching using ICT tools.
\end{abstract}

Keywords: Competence, ICT, Mentoring, Pedagogy, Training

Copyright (c) 2021 Yufita, Hotmaulina Sihotang, Witarsa Tambunan

$\triangle$ Corresponding author

Email : hotmaulina.sihotang@uki.ac.id

DOI : https://doi.org/10.31004/edukatif.v3i6.1283

ISSN 2656-8063 (Media Cetak)

ISSN 2656-8071 (Media Online) 
3994 Peningkatan Kompetensi Pedagogik melalui Pelatihan Teknologi Informasi Komunikasi dan Pendampingan Kepala Sekolah pada Masa Pandemi Covid-19 di Sekolah Dasar - Yufita, Hotmaulina Sihotang, Witarsa Tambunan

DOI: https://doi.org/10.31004/edukatif.v3i6.1283

\section{PENDAHULUAN}

Pandemi Covid-19 yang merebak di seluruh dunia sejak Desember 2019 memberikan dampak pada seluruh aspek khususnya pada pola pendidikan di Indonesia. Surat Edaran Nomor 4 Tahun 2020 yang dikeluarkan Kementerian Pendidikan dan Kebudayaan Indonesia pada tanggal 24 Maret 2020, menegaskan untuk menghentikan seluruh proses kegiatan belajar tatap muka di sekolah dan mengantikan dengan kegiatan pembelajaran jarak jauh secara daring (online) pada semua jenjang pendidikan. Pembelajaran online atau daring memiliki karakteristik terbuka dan terdistribusi sebagai alat bantu pendidikan (perangkat pedagogik), dengan memanfaatkan teknologi berbasis jaringan dan internet dalam menfasilitasi kegiatan pembelajaran dan pembentukan proses pengetahuan melalui tindakan dan interaksi yang bermakna (Astini, 2020; Cholik, 2017). Kegiatan pembelajaran tersebut tentunya sangat bergantung dengan memanfaatkan perangkat teknologi informasi dan komunikasi (TIK) yang terkoneksi pada jaringan internet dalam membantu untuk mengumpulkan sumber-sumber pengetahuan dan menjadi sumber belajar terbuka (Gupta, 2017; Septiana, 2019:5). Selama proses pembelajaran TIK dapat digunakan sebagai media yang memungkinkan terjadinya interaksi belajar, sarana ketersediaan materi belajar, akomodasi produk hasil belajar siswa, dan komunikasi, serta pengembangan profesionalitas guru (Widyastono, 2017).

Kegiatan pembelajaran secara daring (online) melalui perangkat TIK memberikan tuntutan mutlak pada keterampilan guru dalam menggunakan perangkat TIK (Duryat, P.S., \& Duryat, 2019). Guru diharuskan memiliki keterampilan dalam memanfaatkan berbagai fitur yang terdapat pada aplikasi zoom meeting, google classroom atau microsoft teams. Selain itu, guru juga semakin dituntut untuk dapat menyajikan materi pembelajaran yang bermakna, menyampaikan materi pembelajaran yang kreatif dan menarik dengan menggunakan perangkat TIK dan berbagai program komputer. Kecakapan guru dalam mengembangkan kegiatan pembelajaran dengan memanfaatkan TIK, dalam hal perencanaan, pelaksanaan dan evaluasi pembelajararan, menjadi indikator dari pengembangan kompetensi pedagogik guru di abad 21 (Indrawan, 2020:36; Simarmata, dkk, 2020:20). Kompetensi yang dimiliki guru merupakan seperangkat kemampuan dan keterampilan yang patut dimiliki oleh seorang pendidik dalam menjalakan tugas profesi keguruan agar kegiatan pendidikan dapat berlangsung dengan efektif (Darmadi, 2019:79; Sutrisno, 2019:137). Hal ini juga diatur dalam Peraturan Menteri Pendidikan Nasional Nomor 16 tahun 2007 (Batubara, 2017) yang menunjukan bahwa dalam kaitannya dengan kompetensi guru, kompetensi TIK berfungsi sebagai pengembangan diri dan penunjang dalam proses pembelajaran. Kapasitas seorang guru dalam memberikan proses pembelajaran, kemampuan melatih soft skill sebagai bekal kehidupan, kondisi sekolah, kurikulum, faktor teknologi sangat berpengaruh terhadap perkembangan dunia pendidikan di Indonesia. Putra Nababan (dalam Tambunan, 2020) melihat bahwa proses pendidikan di Indonesia pada abad ke 21 seharusnya dipandang dari kedua sisi yaitu supply side dan demand side.

Perubahan metode pembelajaran secara daring (online) nyatanya kurang didukung oleh keterampilan kompetensi Guru. Pemerintah Provinsi DKI Jakarta sebelumnya telah melaksanakan Uji Kompetensi Guru (UKG) pada tahun 2019 untuk mendapatkan gambaran mengenai kompetensi guru-guru DKI Jakarta. Satriwan Salim (2020) dalam artikelnya tentang Catatan Kritis Uji Kompetensi Guru Jakarta, mengungkapkan hasil UKG DKI Jakarta tahun 2019 masih berada di bawah rata-rata, yaitu berada di angka 54. Jika dibandingkan dengan hasil UKG 2015, terdapat penurunan hasil UKG. Berdasarkan data dari buku Neraca Pendidikan Daerah (NPD) yang diterbitkan oleh Kemdikbud pada tahun 2019 hasil rata-rata untuk kompetensi pedagogik pada UKG DKI Jakarta pada 2015 berada diangka 56,74. Dibandingkan dengan hasil UKG DKI Jakarta pada kompetensi professional guru sebesar 65,09, kompetensi pedagogik masih tergolong rendah. Sehingga kompetensi pedagogik menjadi kompetensi utama yang harus ditingkatkan dan dikembangkan oleh 
3995 Peningkatan Kompetensi Pedagogik melalui Pelatihan Teknologi Informasi Komunikasi dan Pendampingan Kepala Sekolah pada Masa Pandemi Covid-19 di Sekolah Dasar - Yufita, Hotmaulina Sihotang, Witarsa Tambunan

DOI: https://doi.org/10.31004/edukatif.v3i6.1283

setiap guru. Indikator kompetensi pedagogik yang perlu ditingkatkan pada masa pandemi covid-19 adalah keterampilan guru dalam memanfaatkan media belajar, khususnya media pembelajaran berbasis teknologi.

Perubahan dan perkembangan jaman yang semakin pesat dan massif mendorong guru untuk menjadi manusia pembelajar yang tak behenti belajar dan selalu mampu beradaptasi dengan perkembangan jaman, kemajuan ilmu pengetahuan dan teknologi, serta mobilitas masyarakat di abad 21 (Keizer, H. \& Pringgabayu, 2017). Guru sebagai komponen utama sumber daya pendidikan yang harus senantiasa mendapatkan pembinaan dan pengembangan agar dapat memaksimalkan potensi dirinya sehingga dapat menjalankan tugasnya secara potensial. Kepala sekolah menjadi penggerak yang memotivasi dan mengajak para guru untuk melakukan perubahan-perubahan terhadap cara kerjanya (Yufita \& Sihotang, 2020). Kepala sekolah adalah pemimpin pendidikan yang memiliki kewenangan dalam mengelola satuan pendidikan, baik pengembangan sumber daya manusia maupun pengembangan dan pemeliharan sarana prasarana yang ada di sekolah dengan baik (Pianda, 2018:80; Suparman, 2019:117; Zainuddin, 2017). Kepala sekolah bertugas melaksanakan kegiatan pemeliharaan dan pengembangan profesi guru dalam hal pengelolaan tenaga kependidikan. Hal ini dilakukan dengan menyediakan dan memberikan kesempatan kepada setiap guru untuk memberdayakan dirinya melalui program pengembangan profesi.

Pengembangan kompetensi guru juga dapat dilakukan melalui pemberdayaan guru. Susanto, (2016:34) menyatakan bahwa dengan pemberdayaan, guru mendapatkan pembelajaran sehingga dapat menhasilkan kondisi professional yang digunakan dalam menjalankan peranannya sebagai pendidik. Kepala sekolah perlu menyusun program pengembangan sumber daya manusia dengan melakukan analisis organisasi, analisis tugas dan analisis orang agar pengembangan sumber daya manusia tepat sasaran (Basri, \& Rusdiana, 2015:16). Nadeak, (2019:98) mengemukakan bahwa dalam proses pembinaan pendidik dan tenaga kependidikan, dapat dilakukan berbagai kegiatan pelatihan dimana guru dapat mengikutinya secara individu ataupun berkelompok dapat dilakukan. Salah satu cara yang dapat dilakukan untuk meningkatkan kemampuan penguasaan dan pemahaman guru dalam memanfaatkan TIK adalah mengadakan pelatihan dan sosialisasi TIK dengan mendatangkan narasumber yang kompeten (Ahmadi, 2017:119; Aka, 2017).

Pelatihan sangat berhubungan dengan kemampuan seseorang agar terbiasa dalam mengerjakan tugastugas pekerjaannya. Pelatihan merupakan serangkaian kegiatan yang secara sistematis diberikan kepada karyawan untuk menambah kemampuan, keahlian, pengetahuan, pengalaman, ataupun perubahan sikap seseorang agar dapat menjalankan tugas pekerjaannya secara professional (Dessler, 2015:284; Kamil, 2010:3; Poltak, 2018:169; Widodo, 2018:82). Pelatihan bagi guru merupakan serangkaian aktivitas yang diberikan kepada guru dengan tujuan untuk menambah keterampilan dan pengetahuannya agar dapat memenuhi tugas professionalnya sesuai dengan tuntutan dan standar yang ada. Kegiatan pelatihan bagi guru merupakan bagian tak terpisahkan dari manajemen sumber daya pendidikan dimana dilakukan upaya untuk mengembangkan pengetahuan dan keterampilan guru sebagai sumber daya pendidik sehingga guru memiliki keunggulan kompetitif sehingga dapat memberikan pelayanan pendidikan dengan baik (Sela, Lengkong, \& Trang, 2018).

Dalam proses mengembangkan profesionalitas guru, kepala sekolah berperan sebagai seorang pengawas (supervisor) yang menilai kinerja guru melalui kegiatan supervisi, pendampingan maupun kegiatan lain (Sulistyorini, dkk 2017). Pendampingan merupakan alat dalam pemberdayaan dan pengembangan individu, yang dilakukan dalam bentuk pemberian bantuan secara berkesinambungan dan terstruktur dari sesorang yang berpengalaman atau memiliki keahlian khusus kepada rekan yang kurang berpengalaman agar dapat mengembangkan potensi dirinya secara optimal (Kholil, 2020; Khotifah, 2020; Noviani, 2019). Dengan kata lain, pendampingan merupakan suatu kemitraan yang melibatkan kerjasama dan kesempatan dalam menghadapi tantangan dan melakukan refleksi yang berkesinambungan dengan melibatkan dua belah pihak yang memiliki koneksivitas. 
SDS Pelita sebagai salah satu sekolah di wilayah Jakarta Barat yang tekena dampak pandemi covid-19 melaksanakan kegiatan belajar dari rumah sejak Maret 2020. Pada awal pandemi covid-19 terjadi, interaksi antara guru dan siswa-siswa SDS Pelita dilakukan melalui aplikasi whatsapp. Setiap hari guru mengirimkan video pembelajaran dan memberi informasi mengenai tugas yang harus dikerjakan oleh siswa melalui whatsapp group kelas. Hal ini dilakukan karena kemampuan penggunaan TIK sebagaian besar guru belum begitu baik. Guru baru belajar menggunakan TIK untuk mengetik soal melalui microsoft word. Pengolahan nilai sebagian besar masih dilakukan secara manual. Hanya beberapa orang guru yang mampu melakukan pengolahan nilai menggunakan microsoft excel. Begitu pula dalam hal penggunaan microsoft power point, sebagaian besar guru belum mampu menggunakannya untuk membuat media pembelajaran. Guru-guru lebih sering memutarkan video pembelajaran yang diunggah melalui youtube.

Pada awal tahun pembelajaran 2020/2021 SDS Pelita mulai melaksanakan kegiatan pembelajaran jarak jauh secara online dengan memanfaatkan aplikasi zoom meeting sebagai sarana komunikasi virtual. Penggunaan aplikasi zoom meeting dalam proses pembelajaran online di SDS Pelita menuntut kemampuan guru dalam menggunakan perangkat TIK. Penggunaan aplikasi zoom meeting dalam kegiatan pembelajaran online di SDS masih terbatas pada kegiatan ceramah dan tanya jawab. Guru-guru belum dapat menyampaikan materi pembelajaran yang menarik. Agar pembelajaran online menggunakan aplikasi zoom meeting lebih menarik bagi peserta didik, guru dapat memanfaatkan program microsoft power point untuk mempresentasikan materi pembelajaran. Keterampilan guru-guru SDS Pelita dalam membuat dan menggunakan media presentasi pembelajaran menggunakan program microsoft power point perlu ditingkatkan. Oleh karena itu diperlukan pelatihan penggunaan TIK, khususnya dalam penggunaan program microsoft power point agar guru-guru SDS Pelita dapat membuat presentasi pembelajaran dan mempresentasikan pembelajaran menggunakan program microsoft power point pada pembelajaran online. Penelitian ini ingin mengetahui dampak pelatihan TIK terhadap peningkatan kompetensi pedagogik guru-guru SDS Pelita pada masa pandemi covid-1 dan mengetahui efektivitas pendampingan kepala sekolah dalam meningkatkan kompetensi pedagogik guru-guru SDS Pelita pada masa pandemi covid-19.

\section{METODE PENELITIAN}

Jenis penelitian yang dilakukan merupakan penelitian tindakan sekolah (school action research) yang akan mengkaji dampak pelatihan TIK pada guru dan pendampingan kepala sekolah terhadap peningkatan kompetensi pedagogik guru. Dalam penelitian tindakan sekolah ini, tindakan yang akan diterapkan adalah pelatihan TIK, khususnya pembuatan presentasi materi pembelajaran menggunakan program microsoft power point, dan pendampingan kepala sekolah. Penelitian tindakan sekolah ini menggunakan model penelitian tindakan Kemmis dan Taggart yang dikenal dengan system spiral reflektif diri. Kemmis, Taggart dan Nixon dalam bukunya The Action Research Planner: Doing Critical Participatory Action Research (2014:18) menggambarkan system spiral reflektif diri dalam rangkaian siklus yang terdiri dari empat kegiatan yaitu perencanaan (planning), pelaksanaan (action), pengamatan (observing), dan refleksi (reflection). Model penelitian tindakan sekolah dari Kemmis dan Taggart digambarkan pada gambar 1. 


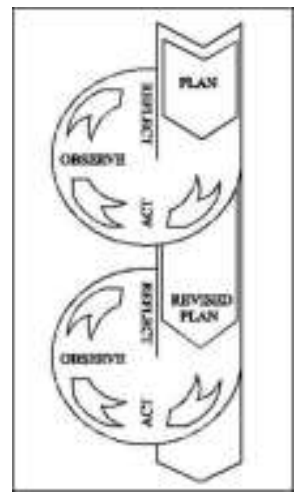

Gambar 1. Siklus Penelititan Tindakan menurut Kemmis dan Taggart (sumber: Setiawati, 2015:35)

Penelitan tindakan sekolah ini akan dilaksanakan di SDS Pelita yang beralamat di Jalan Pos Duri Raya No. 23-29, Kecamatan Tambora, Jakarta Barat. Penelitian akan dilaksanakan pada semester genap tahun pembelajaran 2020 -2021. Responden dalam penelitian tindakan sekolah ini adalah guru kelas di SDS Pelita yang berjumlah 11 orang. Seluruh responden berjenis kelamin perempuan dengan rentang usia $30-70$ tahun. Secara umum kemampuan pedagogik guru-guru kelas tersebut masih berada dibawah rata-rata. Dilihat dari kemampuan penggunaan teknologi pada masa pandemi covid-19 saat ini, guru-guru SDS Pelita mengalami kesulitan dalam menyampaikan pembelajaran menggunakan media TIK.

Sasaran penelitian tindakan sekolah ini adalah peningkatan kompetensi pedagogik, khususnya dalam memanfaatkan TIK sebagai media presentasi pembelajaran. Melalui pelatihan TIK dan pendampingan kepala sekolah diharapkan ada peningkatan kompetensi pedagogik guru, khususnya dalam pemanfaatan TIK. Dalam hal ini pemanfaatan TIK yang dimaksud adalah keterampilan guru dalam menggunakan program microsoft power point untuk membuat presentasi materi pembelajaran dan kemampuan guru dalam mempresentasikan materi pembelajaran yang dibuatnya pada saat pembelajaran online. Kriteria keberhasilan dalam penelitian tindakan sekolah ini adalah jika seluruh guru kelas sebagai responden dalam penelitian ini dapat membuat presentasi pembelajaran menggunakan program microsoft power point dan dapat memanfaatkan program microsoft power point untuk mempresentasikan materi pembelajaran pada saat kegiatan pembelajaran online.

Teknik pengumpulan data yang digunakan dalam penelitian tindakan sekolah ini adalah angket/kuesioner, observasi dan wawancara. Analisa data pada penelitian tindakan sekolah ini menggunakan teknik analisis deskriptif kualitatif, untuk menggambarkan keadaan atau fakta data yang diperoleh pada saat observasi. Data yang didapatkan dalam penelitian tindakan sekolah ini akan dikomparasi setiap siklusnya, untuk memperoleh gambaran peningkatan yang terjadi setelah diberikan tindakan di setiap siklus.

\section{HASIL DAN PEMBAHASAN PENELITIAN}

Data dalam penelitian tindakan sekolah didapatkan melalui angket, observasi dan wawancara. Penelitian tindakan sekolah ini dilakukan di SDS Pelita yang berlokasi di Jalan Pos Duri Raya No. 23-29, Jakarta Barat. Kegiatan penelitian tindakan sekolah dilaksanakan pada tahun pembelajaran 2020 - 2021, dimana kegiatan belajar mengajar dilakukan secara online selama masa pandemic covid-19. SDS Pelita merupakan salah satu sekolah swasta yang berada di wilayah Jakarta Barat yang saat ini terakreditasi dengan nilai "A". SDS Pelita berada dibawah naungan Yayasan Pendidikan Budhi Bakti yang didirikan sejak tahun 1982. Pada tahun pembelajaran 2020-2021, SDS Pelita memiliki kurang lebih 426 siswa yang terbagi dalam 11 kelas. SDS Pelita memiliki karyawan tetap yang terdiri dari 11 orang guru kelas dan 2 tenaga kependidikan. Karyawan tidak tetap terdiri dari 7 orang guru honorer yang mengajar bidang studi tertentu. 
3998 Peningkatan Kompetensi Pedagogik melalui Pelatihan Teknologi Informasi Komunikasi dan Pendampingan Kepala Sekolah pada Masa Pandemi Covid-19 di Sekolah Dasar - Yufita, Hotmaulina Sihotang, Witarsa Tambunan

DOI: https://doi.org/10.31004/edukatif.v3i6.1283

Pada awalnya subjek pada penelitian tindakan sekolah ini adalah 11 orang guru kelas, berjenis kelamin perempuan dengan rentang usia 30 tahun sampai dengan 70 tahun. Namun guru kelas 5B yang telah berusia 70 tahun tidak dapat menjadi responden penelitian karena pandemi covid-19 membuat guru tersebut tidak dapat mengikuti pelatihan secara tatap muka. Maka subjek penelitian berkurang 1 menjadi 10 orang guru kelas. Guru-guru yang menjadi subjek penelitian ini telah mengajar lebih dari 5 tahun. Data guru kelas yang menjadi subjek penelitian tindakan sekolah ini dapat dilihat pada lampiran 5.

Penelitian tindakan sekolah ini dilakukan dalam 2 tahap yaitu siklus I dan siklus II. Sebelum pelaksanaan siklus I, dilakukan pra siklus melalui forum group discussion untuk mengetahui kemampuan guru kelas dalam pemanfaatan TIK.

\section{Pra Siklus}

Hasil forum group discussion yang dilaksanakan pada awal Februari 2021 menunjukkan bahwa sebagian besar guru kelas di SDS Pelita belum benar-benar memanfaatkan TIK sebagai media pembelajaran. Kemampuan guru kelas dalam menggunakan perangkat TIK baru sebatas menggunakan microsoft words, untuk mengetik soal ulangan dan membuat ringkasan materi bagi siswa, dan microsoft excel, untuk pengolahan nilai. Kemampuan guru kelas dalam memanfaatkan TIK masa pandemi covid-19, semakin berkembang dengan keharusan menggunakan aplikasi zoom meeting sebagai platform untuk mengajar secara virtual. Namun dalam forum group discussion, guru kelas menyatakan bahwa mereka masih mengalami kesulitan bila harus membuat media pembelajaran dan menampilkan materi pembelajaran menggunakan microsoft power point.

Selain mengadakan forum group discussion, dilakukan penyebaran angket menggunakan google form untuk mendapatkan gambaran mengenai kompetensi pedagogik guru kelas dalam memanfaatkan TIK. Dari angket yang diberikan, didapatkan data bahwa 10 orang guru kelas berjenis kelamin perempuan dengan kisaran usia 30 tahun sampai 52 tahun. Lama mengajar mulai dari 5 tahun sampai 26 tahun mengajar. Semua responden menyatakan terbiasa mengajar dengan menggunakan media pembelajaran dan telah memanfaatkan berbagai macam media pembelajaran dalam pembelajaran jarak jauh. Selama masa pandemi covid-19, guruguru merasa lebih senang menggunakan media pembelajaran berbasis TIK sebagai alat bantu mengajar. Namun masih ditemukan responden yang mengalami kesulitan dalam mengajar menggunakan media pembelajaran berbasis TIK. Sebagian guru menyatakan telah memahami program microsoft power point untuk membuat media pembelajaran. Namun, masih ditemukan 2 orang guru yang tidak memahami penggunaan program microsoft power point untuk membuat media pembelajaran.

Dari angket yang diberikan, sebagian besar guru menyatakan dapat menggunakan program microsoft power point dalam mempresentasikan pembelajaran, namun 4 orang guru masih mengalamai kesulitan dalam penggunaan program microsoft power point sebagai media untuk menyampaikan materi pembelajaran. $40 \%$ guru lebih sering menggunakan media pembelajaran yang tersedia di internet dari pada membuat sendiri. Sebagian besar guru menyatakan pernah mengikuti pelatihan atau kegiatan sejenisnya tentang penggunaan media pembelajaran berbasis TIK. $70 \%$ responden menyatakan belajar sendiri tentang penggunaan media pembelajaran berbasis TIK. Semua guru menerapkan hasil pelatihan TIK dalam proses belajar mengajar.

Dari hasil angket dan forum group discussion, masih ditemukan guru-guru yang belum dapat menggunakan program microsoft power point, sehingga dilakukan tindakan pelatihan pembuatan media pembelajaran menggunakan program microsoft power point.

2. Siklus I

a. Tahap Perencanaan 
3999 Peningkatan Kompetensi Pedagogik melalui Pelatihan Teknologi Informasi Komunikasi dan Pendampingan Kepala Sekolah pada Masa Pandemi Covid-19 di Sekolah Dasar - Yufita, Hotmaulina Sihotang, Witarsa Tambunan

DOI: https://doi.org/10.31004/edukatif.v3i6.1283

Berdasarkan hasil forum group discussion dan angket kompetensi pedagogik guru dalam pemanfaatan TIK, tindakan yang akan diberikan kepada guru-guru SDS Pelita untuk meningkatkan kompetensi pedagogik khususnya dalam pemanfaatan TIK adalah pelatihan pembuatan media pembelajaran menggunakan program microsoft power point. Perencanaan yang dilakukan adalah sebagai berikut:

1) Menghubungi narasumber untuk pelatihan dan menyiapkan materi pelatihan sesuai dengan kebutuhan guru-guru kelas SDS Pelita.

2) Mempersiapkan instrumen yang akan digunakan sebagai alat bantu dalam mengobservasi penelitian tindakan sekolah, yang terdiri dari lembar observasi perilaku dan keterampilan guru dalam membuat media pembelajaran, lembar observasi aktivitas guru dalam memanfaatakan penggunaan TIK dan pedoman wawancara.

3) Mengatur waktu pelaksanaan kegiatan pelatihan TIK dan menyusun jadwal observasi setelah pelatihan berlangsung.

b. Pelaksanaan Tindakan

Siklus ke-1 dari penelitian tindakan kelas ini dilaksanakan pada tanggal 5 Maret 2021. Kegiatan pelatihan TIK dimulai pukul 08.00 - 16.00. Kegiatan pelatihan diikuti oleh 10 orang guru kelas SDS Pelita. Satu orang guru kelas yang telah memasuki usia pensiun tidak dapat mengikuti pelatihan dikarenakan situasi pandemi covid-19. Kegiatan pelatihan pada siklus 1 diawali dengan pengarahan dari kepala sekolah terkait kegiatan pelatihan yang akan diikuti oleh para guru. Pada gambar 2 tampak peserta pelatihan mendapatkan pengarahan dari Kepala Sekolah tentang kegiatan pelatihan.

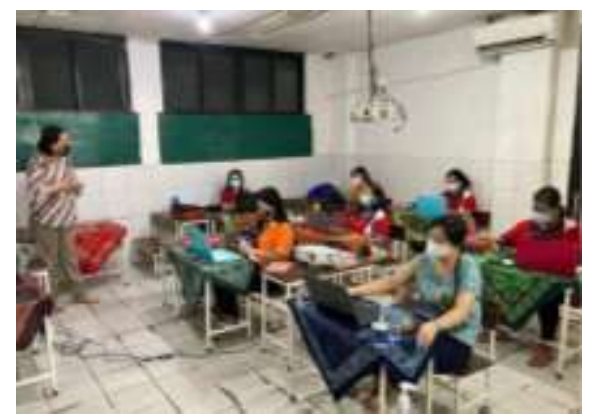

Gambar 2. Pengarahan Kepala Sekolah pada Kegiatan Pelatihan Siklus 1

Pada gambar 2 narasumber pelatihan, Bapak Carolino Benedicto, yang menyampaikan materi tentang cara membuat presentasi materi pembelajaran menggunakan microsoft power point. Materi pelatihan yang diberikan merupakan keterampilan dasar dalam penggunaan program microsoft power point yang meliputi keterampilan dalam memilih layout, membuat background, menformat teks, menformat gambar, memberi efek bentuk pada teks atau gambar, animasi teks, animasi gambar dan cara menambah efek suara. Narasumber mempresentasikan materi pelatihan, memberikan contoh dan mengajak peserta pelatihan untuk mempraktekannya. Narasumber juga secara langsung memberikan pendampingan kepada peserta pelatihan yang mengalami kesulitan dalam membuat media pembelajaran menggunakan program microsoft power point. 


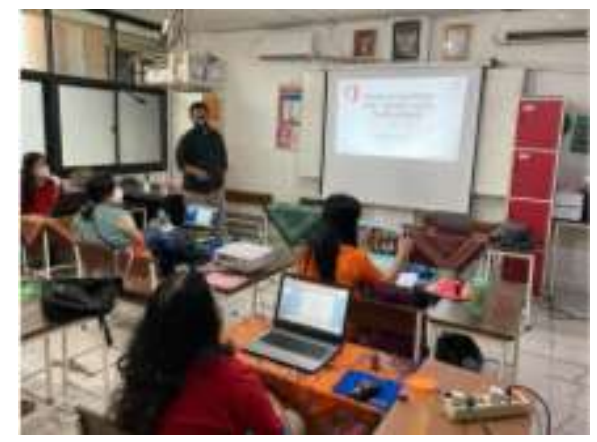

Gambar 3. Narasumber menyampaikan Materi Kegiatan Pelatihan Siklus 1

\section{c. Observasi}

Kegiatan observasi dibagi dalam dua tahap, yaitu pada saat kegiatan pelatihan TIK berlangsung dan setelah kegiatan pelatihan TIK. Setelah kegiatan pelatihan TIK, observasi dilakukan dengan cara mengamati kegiatan belajar mengajar online yang dilaksanakan guru selama masa pandemic covid-19. Hasil observasi terhadap perilaku guru dalam mengikuti pelatihan pada siklus ke-1 ditemukan 60\% guru sangat serius, 20\% serius dan 20\% guru kurang serius. Masih ditemukan 2 orang guru yang kurang serius dalam mengikuti pelatihan. Kurang seriusnya guru dalam mengikuti kegiatan pelatihan apda siklus ke-1 tampak dari semangat guru, kurangnya perhatian guru terhadap penjelasan narasumber, kurangnya rasa ingin tahu, dan selalu mengharapkan bantuan dari orang lain dalam membuat presentasi pembelajaran menggunakan program microsoft power point.

Keterampilan guru dalam membuat presentasi materi pembelajaran menggunakan program microsoft power point pada siklus ke-1, 50\% guru masuk dalam kategori terampil dan sangat terampil sedangkan 50\% guru masih berada dalam kategori kurang terampil dan tidak terampil dalam membuat presentasi pembelajaran menggunakan program microsoft power point. Membuat presentasi pembelajaran menggunakan program microsoft power point menjadi pengalaman baru bagi ketiga guru tersebut. Sehingga mereka sesekali masih membutuhkan bantuan orang lain saat memilih layout slide, membuat background, memformat teks, memformat gambar dan memberi efek bentuk pada teks/gambar.

Setelah kegiatan pelatihan, observasi dilakukan untuk melihat sejauh mana pemanfaatan TIK dalam kegiatan belajar mengajar secara online. Hasil observasi terhadap aktivitas guru dalam memanfaatkan penggunaan TIK didapatkan sebanyak $40 \%$ guru kurang baik dalam aktivitas memanfaatkan TIK dalam pembelajaran. Khususnya untuk indikator penggunaan media pembelajaran TIK dalam mempresentasikan pembelajaran ditemukan 4 orang guru yang hanya sekedar menggunakan program microsoft power point namun masih belum dapat memperhatikan kualitas dalam pembuatan presentasi pembelajaran yang akan ditampilkan. Presentasi pembelajaran masih kurang menarik dan tidak terbaca dengan baik oleh peserta didik karena pemilihan huruf yang terlalu kecil. Maka ke-4 orang guru ini mendapatkan pendampingan secara khusus dalam pembuatan presentasi pembelajaran pada pelatihan siklus ke-2.

d. Refleksi

Refleksi dilakukan dengan menganalisis hasil observasi dan berdiskusi bersama dengan narasumber kegiatan pelatihan untuk menilai kompetensi pedagogik guru pelatihan TIK. Dari wawancara yang dilakukan ditemukan beberapa kendala yang dihadapi responden dalam menggunakan media pembelajaran berbasis TIK seperti ketidakmampuan guru dalam menggunakan program microsoft power point, guru belum memiliki keterampilan dalam membuat presentasi materi pembelajaran menggunakan microsoft power point. Selain itu responden juga menyatakan adanya keterbatasan waktu dalam menyiapkan presentasi materi pembelajaran menggunakan microsoft power point. 
4001 Peningkatan Kompetensi Pedagogik melalui Pelatihan Teknologi Informasi Komunikasi dan Pendampingan Kepala Sekolah pada Masa Pandemi Covid-19 di Sekolah Dasar - Yufita, Hotmaulina Sihotang, Witarsa Tambunan

DOI: https://doi.org/10.31004/edukatif.v3i6.1283

Kegiatan pelatihan TIK, khususnya pembuatan dan pemanfaatan media pembelajaran menggunakan microsoft power point pada siklus ke-1 dinilai terlalu singkat. Pelatihan yang dilaksanakan selama kurang lebih 8 jam, belum dapat memaksimalkan kemampuan guru dalam membuat presentasi materi pembelajaran menggunakan program microsoft power point. Responden harus menyiapkan waktu khusus untuk menyelesaikan presentasi materi pembelajaran yang dibuatnya saat itu agar dapat digunakan dalam proses pembelajaran secara online.

Guru masih enggan menyampaikan materi pembelajaran menggunakan presentasi power point. Guru merasa lebih mudah menerangkan pembelajaran dengan menulis di papan tulis yang tersorot ke kamera pada saat pembelajaran online. Masih ditemukan guru yang belum dapat mempresentasikan materi pembelajaran yang dibuat menggunakan program microsoft power point.

Dari hasil refleksi siklus ke-1, maka diperlukan perbaikan tindakan pelatihan TIK khususnya pembuatan dan pemanfaatan media pembelajaran menggunakan program microsoft power point. Kegiatan pelatihan yang akan dilaksanakan pada siklus ke-2 harus lebih menekankan praktek langsung dan pendampingan khusus bagi setiap guru yang masih belum terampil dalam membuat presentasi materi pembelajaran menggunakan program microsoft power point.

\section{Siklus II}

Kegiatan pada siklus ke-2 diawali dengan merancang kembali kegiatan pelatihan TIK, khususnya dalam pembuatan dan pemanfaatan media presentasi materi pembelajaran menggunakan program microsoft power point dengan memperhatikan hasil refleksi pada siklus ke-1.

a. Tahap Perencanaan

Berdasarkan hasil refleksi siklus ke-1, maka rencana perbaikan tindakan yang akan diberikan pada siklus ke-2 tetap menekankan pada pelatihan TIK namun dengan penekanan pada praktek pembuatan media presentasi pembelajaran secara langsung, menambah durasi pelatihan menjadi dua hari dan menerapkan tutor sebaya dalam proses pembuatan media presentasi pembelajaran.

\section{b. Pelaksanaan Tindakan}

Siklus ke-2 dari penelitian tindakan sekolah ini dilaksanakan selama dua hari yaitu pada tanggal 6 dan 7 Mei 2021. Pelatihan diikuti oleh 10 orang guru kelas yang telah mengikuti pelatihan pada siklus ke-1. Pada hari pertama, 6 Mei 2021, kegiatan pelatihan diawali dengan pengarahan singkat dari narasumber, dilanjutkan dengan praktek pembuatan presentasi materi pembelajaran menggunanakan program microsoft power point secara langsung. Kegiatan pelatihan pada hari pertama diakhiri pada pukul 16.00. Pada akhir kegiatan hari pertama, dilakukan pemantauan sejauh mana guru dapat menyelesaikan media pembelajaran yang dibuatnya. Kegiatan pada hari ke-2, 7 Mei 2021, lebih berfokus pada upaya guru dalam menyelesaikan presentasi materi pembelajaran yang dibuat pada hari sebelumnya. Kegiatan pelatihan diakhiri pada pukul 15.00, pada saat semua guru telah berhasil menyelesaikan pembuatan presentasi materi pembelajaran menggunakan program microsoft power point.

Pada pelatihan siklus ke-2 guru berkerja secara berkelompok seperti pada gambar 4 yang menunjukkan upaya guru dalam membuat presentasi pembelajaran menggunakan microsoft power point dengan cara bekerja sama dengan rekan sejawat. 
4002 Peningkatan Kompetensi Pedagogik melalui Pelatihan Teknologi Informasi Komunikasi dan Pendampingan Kepala Sekolah pada Masa Pandemi Covid-19 di Sekolah Dasar - Yufita, Hotmaulina Sihotang, Witarsa Tambunan

DOI: https://doi.org/10.31004/edukatif.v3i6.1283

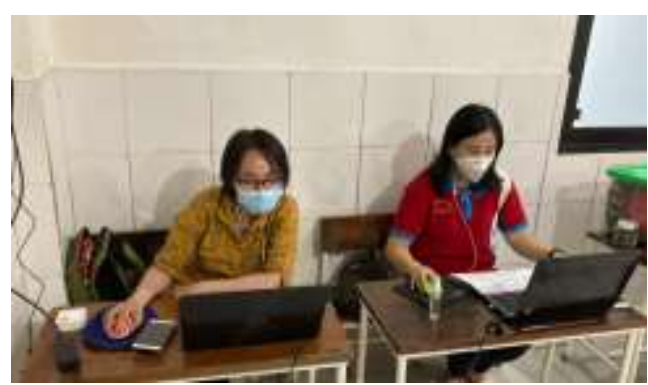

Gambar 4. Bekerjasama dengan rekan sejawat dalam kegiatan pelatihan siklus 2

Pada gambar 5 tampak salah satu guru bidang studi yang diminta secara khusus membantu memberikan pendampingan terhadap guru yang mengalami kesulitan dalam menggunakan program microsoft power point.

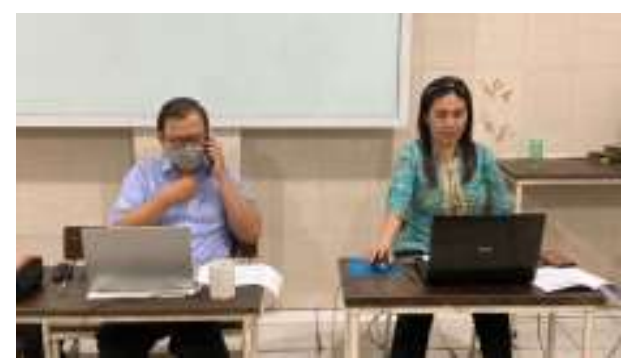

Gambar 5. Pendampingan dari rekan sejawat dalam kegiatan pelatihan Siklus 2

c. Observasi

Pada siklus ke-2 dilakukan pengamatan terhadap perilaku dan kererampilan guru dalam membuat media pembelajaran menggunakan microsoft power point. Pada siklus ke-2, guru-guru tampak lebih bersemangat mengikuti pelatihan dan mempersiapkan diri dengan baik. Guru mulai menyadari pentingnya pemanfaatan program microsoft power point sebagai media untuk mempresentasikan pembelajaran berbasis TIK. Salah seorang guru menyatakan bahwa pemanfaatan program microsoft power point sebagai media untuk mempresentasikan pembelajaran berbasis TIK membuat proses pembelajaran online lebih menyenangkan sehingga peserta didik dapat lebih fokus belajar dalam kegiatan pembelajaran online.

Hasil karya guru berupa presentasi materi pembelajaran menggunakan program microsoft power point yang telah dibuat dalam pelatihan TIK kemudian digunakan dalam kegiatan pembelajaran online seperti tampak pada gambar 6 .

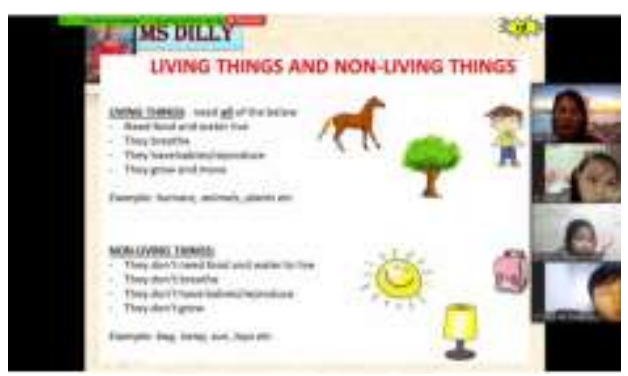

Gambar 6. Mempresentasikan presentasi pembelajaran menggunakan Power Point pada saat pembelajaran online 
4003 Peningkatan Kompetensi Pedagogik melalui Pelatihan Teknologi Informasi Komunikasi dan Pendampingan Kepala Sekolah pada Masa Pandemi Covid-19 di Sekolah Dasar - Yufita, Hotmaulina Sihotang, Witarsa Tambunan

DOI: https://doi.org/10.31004/edukatif.v3i6.1283

\section{d. Refleksi}

Hasil observasi terhadap kegiatan pelatihan TIK yang dilaksanakan pada siklus ke-2 ditemukan adanya peningkatan terhadap kemampuan guru dalam pemanfaatan TIK. Semua responden dalam penelitian ini memiliki keterampilan dalam membuat presentasi materi pembelajaran menggunakan program microsoft power point. Kompetensi pedagogik khususnya dalam pemanfaatan TIK terlihat meingkat dengan kemampuan guru mempresentatikan materi pembelajaran menggunakan program microsoft power point pada saat kegiatan belajar mengajar online di kelas.

Pada siklus ke-2, terdapat peningkatan dalam keterampilan guru membuat presentasi materi pembelajaran menggunakan program microsoft power point. Pada pelatihan siklus ke-2 yang lebih menekankan praktek pembuatan presentasi materi pembelajaran, guru-guru mendapat pendampingan dari kepala sekolah, narasumber dan rekan sejawat yang lebih mahir dalam membuat presentasi pembelajaran menggunakan program microsoft power point. Dari hasil observasi didapatkan bahwa melalui pendampingan yang diberikan pada pelatihan siklus ke-2, membuat guru-guru dapat lebih terampil dalam membuat presentasi materi pembelajaran menggunakan microsoft power point. Peningkatan keterampilan guru dalam membuat presentasi materi pembelajaran menggunakan program microsoft power point tampak pada indikator keterampilan memilih layout, membuat background, memformat terks dan memformat gambar.

Pendampingan kepala sekolah dapat dikatakan efektif dalam meningkatkan kompetensi pedagogik guru-guru SDS Pelita pada masa pandemi covid-19. Hal ini sejalan dengan hasil penelitian Rahman, M. A., Santosa, A. B., \& Sihotang, H. (2020) kepemimpinan kepala sekolah berpengaruh positif terhadap kinerja guru. Sejalan dengan hasil penelitian Riski, H., Rusdinal, R., \& Gistituti, N. (2021) kepala sekolah mendukung aktivitas guru, kepala sekolah supel dan mau menerima perubahan yang disampaikan oleh bawah. Adanya kesepakatan awal antara kepala sekolah dan guru yang dilakukan pada awal siklus ke-2 dimana setiap guru setuju untuk menghasilkan satu presentasi materi pembelajaran menggunakan program microsoft power point pada kegiatan pelatihan siklus ke-2, membuat guru berusaha untuk dapat mengatasi kendala pemanfaatan TIK. Guru menjadi lebih termotivasi untuk bisa menguasai program microsoft power point agar dapat digunakan pada saat pembelajaran online.

Berdasarkan hasil wawancara dan diskusi dengan para guru, Kepala sekolah menentukan fokus pendampingan kepada guru 1, guru 2 dan guru 8 yang sangat membutuhkan pendampingan dalam pembuatan presentasi pembelajaran menggunakan program microsoft power point. Kepala sekolah meminta bantuan dari guru bidang studi untuk dapat terlibat memberikan bantuan kepada guru 1, guru 2 dan guru 8 selama kegiatan pelatihan. Dari hasil pengamatan peneliti selama kegiatan pelatihan siklus ke-2 berlangsung didapatkan bahwa peran tutor sebaya sangat bermanfaat dalam mengatasi kendala pemanfaatan TIK. Guru-guru lebih merasa nyaman dan terbantu saat belajar bersama dengan rekan guru yang lain.

Kegiatan pendampingan terhadap guru yang mengalami kesulitan tidak hanya dilakukan oleh kepala sekolah pada saat kegiatan pelatihan berlangsung. Kepala sekolah tetap memberikan pendampingan secara berkelanjutan kepada setiap guru dengan memotivasi para guru agar dalam kegiatan belajar online mereka dapat mempresentasikan presentasi pembelajaran yang telah dibuatnya. Penelitian Maladerita, W., Dahliana, D., Ratih, M., \& Rifma, R. (2019) kegiatan supervisi supervisi sangat membantu bagi guru dalam memecahkan masalah-masalah pendidikan yang dihadapi guru pada saat melakukan pembelajaran, serta dapat memberikan motivasi bagi guru agar selalu meningkatkan pengetahuan untuk menjadi guru yang professional dalam melaksanakan pembelajaran. 
4004 Peningkatan Kompetensi Pedagogik melalui Pelatihan Teknologi Informasi Komunikasi dan Pendampingan Kepala Sekolah pada Masa Pandemi Covid-19 di Sekolah Dasar - Yufita, Hotmaulina Sihotang, Witarsa Tambunan

DOI: https://doi.org/10.31004/edukatif.v3i6.1283

\section{KESIMPULAN}

Berdasarkan hasil penelitian dari siklus I dan II, dapat disimpulkan bahwa pelatihan TIK, khususnya pelatihan penggunaan program microsoft power point untuk membuat presentasi materi pembelajaran menggunakan program microsoft power point, dapat membuat kompetensi pedagogik guru di SDS Pelita pada masa pandemi covid-19 semakin meningkat. Perilaku guru dalam mengikuti kegiatan pelatihan terdapat peningkatan khususnya pada usaha guru untuk memahami dan menguasai materi pelatihan. Dalam hal keterampilan membuat presentasi pembelajaran menggunakan program microsoft power point terdapat peningkatan khususnya dalam keterampilan memilih layout, membuat background, memformat teks dan memformat gambar. Dalam aktivitas guru memanfaatkan TIK, peningkatan terjadi pada indikator pemanfaatan TIK pada proses pembelajaran. Guru dapat memanfaatkan TIK dalam mengelola pembelajaran online selama pandemi covid-19 dengan menyajikan presentasi materi pembelajaran hasil karyanya sendiri menggunakan program microsoft power point. Terbukti bahwa pendampingan kepala sekolah yang dilakukan di SDS Pelita efektif dalam meningkatkan kompetensi pedagogik guru-guru SDS Pelita pada masa pandemi covid-1. Pendampingan kepala sekolah menjadi lebih efektif setelah ada kesepakatan awal pada siklus ke-2 dimana setiap guru setuju untuk membuat satu presentasi pembelajaran menggunakan program microsoft power point yang dapat digunakan dalam kegiatan belajar online semasa pandemi covid-19. Efektivitas pendampingan kepala sekolah terlihat dari keseriusan guru dalam mengikuti kegiatan pelatihan siklus ke-2. Guru berusaha untuk mengatasi kendala dalam memanfaatkan TIK dengan cara bertanya kepada narasumber pelatihan dan teman yang lebih mengerti.

\section{DAFTAR PUSTAKA}

Agustian, M., Wijaya, D., \& Kurnia, I. (2019). Keterampilan Dasar Dalam Proses Pembelajaran. Jakarta: Unika Atma Jaya.

Ahmadi, F. (2017). Guru SD Di Era Digital: Pendekatan, Media, Inovasi. CV. Pilar Nusantara.

Aka, K. A. (2017). Pemanfaatan Teknologi Informasi Dan Komunikasi (TIK) Sebagai Wujud Inovasi Sumber Belajar Di Sekolah Dasar. ELSE (Elementary School Education Journal): Jurnal Pendidikan Dan Pembelajaran Sekolah Dasar, 1(2a), 28-37. Https://Doi.Org/10.30651/Else.V1i2a.1041

Astini, N. K. S. (2020). Pemanfaatan Teknologi Informasi Dalam Pembelajaran Tingkat Sekolah Dasar Pada Masa Pandemi Covid-19. Lampuhyang, $\quad 11(2), \quad$ 13-25. Https://Doi.Org/10.47730/Jurnallampuhyang.V11i2.194

Basri, H., \& Rusdiana, A. (2015). Manajemen Pendidikan Dan Pelatihan. CV Pustaka Setia.

Batubara, D. S. (2017). Kompetensi Teknologi Informasi Dan Komunikasi Guru SD/MI (Potret, FaktorFaktor, Dan Upaya Meningkatkannya). Muallimuna: Jurnal Madrasah Ibtidaiyah, 3(1), 48-65. Https://Doi.Org/10.31602/Muallimuna.V3i1

Keizer, H. \& Pringgabayu, B. (2017). Pengaruh Kepemimpinan Kepala Sekolah, Motivasi, Dan Budaya Sekolah, Terhadap Kinerja Guru Di SMK ICB Cinta Niaga Kota Bandung. Jurnal Manajemen Bisnis Dan Inovasi., 4(1), 14-25. Https://Doi.Org/10.35794/Jmbi.V4i1.17402

Cholik, C. A. (2017). Pemanfaatan Teknologi Informasi Dan Komunikasi Untuk Meningkatkan Pendidikan Di Indonesia. Syntax Literate; Jurnal Ilmiah Indonesia, 2(6). Retrieved From Https://Jurnal.Syntaxliterate.Co.Id/Index.Php/Syntax-Literate/Article/View/130

Darmadi, H. (2019). Pengantar Pendidikan Era Globalisasi: Konsep Dasar, Teori, Strategi Dan Implementasi Dalam Pendidikan Globalisasi. An1mage.

Dessler, G. (2015). Human Resource Management (14th Ed). Pearson Education. 
4005 Peningkatan Kompetensi Pedagogik melalui Pelatihan Teknologi Informasi Komunikasi dan Pendampingan Kepala Sekolah pada Masa Pandemi Covid-19 di Sekolah Dasar - Yufita, Hotmaulina Sihotang, Witarsa Tambunan

DOI: https://doi.org/10.31004/edukatif.v3i6.1283

Duryat, P.S., \& Duryat, M. (2019). Paradigma Baru Manajemen Sekolah Di Era Industri 4.0. CV.Alfabeta.

Gupta, R. (2017). Impact Of ICT In Distance Education And Teacher Perception Towards Knowledge Of ICT Tools. International Journal Of Research-GRANTHAALAYAH, 5(1), 163-171. Https://Doi.Org/10.29121/Granthaalayah.V5.I1.2017.1731.

Indrawan, I, Dkk. (2020). Guru Profesional. Lakeisha.

Janawi. (2019). Kompetensi Guru: Citra Guru Profesional. CV. Alfabeta.

Kamil, M. (2010). Model Pendidikan Dan Pelatihan: Konsep Dan Aplikasi. CV. Alfabeta.

Keizer, H. \& Pringgabayu, B. (2017). Pengaruh Kepemimpinan Kepala Sekolah, Motivasi, Dan Budaya Sekolah, Terhadap Kinerja Guru Di SMK ICB Cinta Niaga Kota Bandung. Jurnal Manajemen Bisnis Dan Inovasi., 4(1), 14-25. Https://Doi.Org/10.35794/Jmbi.V4i1.17402

Kemmis, S., Taggart, R.M. \& Nixon, R. (2014). The Action Research Planner: Doing Critical Participatory Action Research. Springer.

Kholil, A. (2020). Dampak Pendampingan Kepala Sekolah Secara Berkelanjutan Terhadap Kemampuan Guru Dalam Memahami Buku Duru Dan Buku Siswa. Jurnal Inovasi Pembelajaran Karakter, 5(1), 1-8. Retrieved From I-Rpp.Com/Index.Php/Jipk/Article/View/1083/371371579

Khotifah, S. (2020). Peningkatan Kompetensi Guru Kelas Dalam Penyusunan Soal Hots Melalui Pendampingan Kepala Sekolah Di SDN Oro-Oro Ombo Tahun Pelajaran 2019/2020. Jurnal Edukasi Gemilang (JEG), 5(3), 18-25. $\quad$ Retrieved $\quad$ From Https://Www.Ejurnalkotamadiun.Org/Index.Php/JEG/Article/View/582/527

Maladerita, W., Dahliana, D., Ratih, M., \& Rifma, R. (2019). Impelementasi Supervisi Dalam Meningkatkan Proses Pembelajaran Dan Pendidikan Karakter Di Sekolah Dasar. Edukatif. Jurnal Ilmu Pendidikan, 1(3), 198-204.

Musfah, J. (2012). Peningkatan Kompetensi Guru Melalui Pelatihan Dan Sumber Belajar Teori Dan Praktik. Kencana.

Nadeak, B. (2019). Manajemen Sumber Daya Manusia Pendidikan Era Industri 4.0. UKI Press.

Noviani, B. F. (2019). (2019). Meningkatkan Kompetensi Guru Kelas Dalam Penyusunan Rpp Melalui Pendampingan Berbasis Kkg Di SD Negeri 34 Mataram Semester Dua Tahun Pelajaran 2017/2018. Media Bina Ilmiah, 13(9), 1593-1604. Https://Doi.Org/10.33758/Mbi.V13i9

Pianda, D. (2018). Kinerja Guru: Kompetensi, Motivasi Kerja, Kepemimpinan Kepala Sekolah. CV. Jejak.

Poltak. (2018). Manajemen Sumber Daya Manusia Membangun Tim Kerja Yang Solid Untuk Membangun Kerja. PT. Bumi Askara.

Rahman, M. A., Santosa, A. B., \& Sihotang, H. (2020). The The Influence Of Principal's Leadership, Teacher Performance And Internal Quality Assurance System In Improving The Quality Of Education In Vocational High School. Jurnal Manajemen Pendidikan, 7(2), 162-175.

Riski, H., Rusdinal, R., \& Gistituti, N. (2021). Kepemimpinan Kepala Sekolah Di Sekolah Menengah Pertama. EDUKATIF: JURNAL ILMU PENDIDIKAN, 3(6), 3531-3537.

Riswadi. (2018). Kompetensi Guru Profesional. Uwais Inspirasi Indonesia.

Robbins, S. P. \& Judge, T. A. (2017). Perilaku Organisasi ((16th Ed); Ratna Saraswati \&Febriella Sirait, Ed.). Salemba Empat.

Safitri, D. (2019). Menjadi Guru Profesional. PT. Indragiri Dot Com.

Sela, J., Lengkong, V. P., \& Trang, I. (2018). Pengaruh Kompetensi Dan Desain Pelatihan Terhadap Efektivitas Pelatihan Guru SMA/SMK/MA Manado Pada Dinas Pendidikan Daerah Provinsi Sulawesi 
4006 Peningkatan Kompetensi Pedagogik melalui Pelatihan Teknologi Informasi Komunikasi dan Pendampingan Kepala Sekolah pada Masa Pandemi Covid-19 di Sekolah Dasar - Yufita, Hotmaulina Sihotang, Witarsa Tambunan

DOI: https://doi.org/10.31004/edukatif.v3i6.1283

Utara. Jurnal EMBA: Jurnal Riset Ekonomi, Manajemen, Bisnis Dan Akuntansi, 6(4), 2368-2377. Https://Doi.Org/10.35794/Emba.V6i4.21004

Septiana, N. (2019). ICT Dalam Pembelajaran MI/SD. Duta Media Publishing.

Setiawati, A. (2015). Penerapan Model Pembelajaran Kooperatif Tipe STAD Untuk Meningkatkan Proses Dan Hasil Belajar IPS Di SD. Doctoral Dissertation, Universitas Pendidikan Indonesia. Http://Repository.Upi.Edu/18257/

Simarmata, J. Hamid, M.A., Ramadhani, R., Chamidah D., Simanihuruk, L., Safitri, M., Napitupulu, D., Iqbal, M., \& Salim, N. A. (2020). Pendidikan Di Era Revolusi 4.0: Tuntutan, Kompetensi \&Tantangan. Yayasan Kita Menulis.

Spencer, M. L. \& Spencer, M. S. (1993). Competence At Work. John Wiley \& Sons, Inc.

Sulistyorini, S., Parmin, \& Samadhy, U. (2017). Model Pendampingan Peningkatan Profesionalisme Guru SD Melalui Supervise Klinis Di Kecamatan Gajah Mungkur Kota Semarang. Jurnal Kreatif: Jurnal Kependidikan Dasar, 7(2), 143-154. Https://Doi.Org/10.15294/Kreatif.V7i2.9376

Suparman. (2019). Kepemimpinan Kepala Sekolah Dan Guru. Uwais Inspirasi Indonesia.

Susanto, A. (2016). Manajemen Peningkatan Kinerja Guru: Konsep Strategi Dan Implementasinya. Prenada Media Group.

Sutrisno, T. (2019). Keterampilan Dasar Mengajar (The Art Of Basic Teaching). Duta Media Publishing \& IAIN Madura.

Tambunan, W. (2020). 65 Tahun Hidup Dalam Kebhinekaan: Pandangan Kritis Dari Sisi Pendidikan Politik. Literasi Nusantara.

Widodo, S. E. (2018). Manajemen Pengembangan Sumber Daya Manusia. Pustaka Belajar.

Widyastono, H. (2017). Pemanfaatan Teknologi Informasi Dan Komunikasi Pada Sekolah Menengah Pertama Negeri Akreditasi A Di Provinsi Jawa Timur. Kwangsan, 5(1), 21-38. Https://Doi.Org/10.31800/Jtp.Kw.V5n1.P21--38

Wijaya, I. (2018). Professional Teacher: Menjadi Guru Profesional. CV. Jejak.

Yufita \& Sihotang, H. (2020). Kepemimpinan Transformasional Dan Pemberdayaan Guru Dalam Transformasi Pendidikan 4.0. Jurnal Dinamika Pendidikan, 13(2), 204-215. Https://Doi.Org/10.51212/Jdp.V13i2.1694

Zainuddin, Z. (2017). Strategi Kepemimpinan Kepala Sekolah Dalam Meningkatkan Kinerja Guru Di Madrasah Aliyah Negeri Kabanjahe. Benchmarking-Jurnal Manajemen Pendidikan Islam, 1(2), 82-88. Http://Jurnal.Uinsu.Ac.Id/Index.Php/Benchmarking/Article/View/1134/903 